\title{
The use of Salvinia auriculata as a bioindicator in aquatic ecosystems: biomass and structure dependent on the cadmium concentration
}

\author{
Wolff, G. ${ }^{a *}$, Pereira, GC. ${ }^{a, c}$, Castro, EM. ${ }^{b}$, Louzada, J. ${ }^{a}$ and Coelho, FF. ${ }^{a, b}$ \\ ${ }^{a}$ Setor de Ecologia e Conservação, Departamento de Biologia, Universidade Federal de Lavras - UFLA, \\ CP 3037, CEP 37200-000, Lavras, MG, Brazil

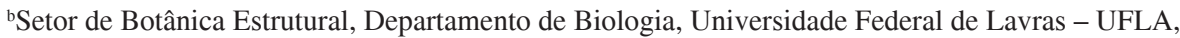 \\ CP 3037, CEP 37200-000, Lavras, MG, Brazil \\ 'Instituto Federal Sudeste de Minas Gerais, Rua Monsenhor José Augusto, 204, São José, \\ Campus Barbacena, CEP 36205-018, Barbacena , MG, Brazil \\ *e-mail grazielewolff@gmail.com
}

Received November 25, 2010 - Accepted February 4, 2011 - Distributed February 29, 2012

(With 2 figures)

\begin{abstract}
This study shows, in a multiple-level approach, the responses of Salvinia auriculata to Cd pollution in aquatic ecosystems. S. auriculata ramets were cultivated in nutrient solution and subjected to five treatments with $\mathrm{Cd}$ for ten days. At the end of the experiment, the number of new ramets and the dry biomass were determined. For ultrastructural observations, the leaves of $S$. auriculata were analyzed using a scanning electron microscope and transmission electron microscope. At the end of the experiment, the plants exposed to Cd showed damage in the leaves including necrosis and chlorosis, stomate deformations and damaged trichomes. We observed a decrease in the number of new ramets and dry biomass of S. auriculata following the increase in Cd concentration in the solution. At the ultrastructural level, leaves exposed to $\mathrm{Cd}$ presented chloroplast deformations and deterioration in the cell wall. All the symptoms of toxicity were directly proportionate to the concentration of $\mathrm{Cd}$ in the solution. The results suggests that $S$. auriculata shows good potential for use as a bioindicator and it can be used in the biomonitoring of aquatic ecosystems contaminated by $\mathrm{Cd}$.
\end{abstract}

Keywords: aquatic plant, heavy metal, ecological indicator, biomonitoring.

\section{O uso de Salvinia auriculata como bioindicador em ecossistemas aquáticos: biomassa e estrutura dependentes da concentração de cádmio}

\begin{abstract}
Resumo
Este estudo apresenta, em diferentes níveis de abordagem, a resposta de Salvinia auriculata à poluição de ecossistemas aquáticos por cádmio (Cd). Rametes de S. auriculata foram cultivados em solução nutritiva e expostos a cinco tratamentos com Cd durante dez dias. Ao final do experimento, o número de novos rametes e a biomassa seca foram determinados. Para observações ultraestruturais, as folhas de $S$. auriculata foram analisadas utilizando-se um microscópio eletrônico de varredura e a microscopia eletrônica de transmissão. Ao final do experimento, as plantas expostas ao Cd apresentaram danos nas folhas, como necrose e clorose, além de estômatos deformados e tricomas danificados. Foi observado um menor número de rametes e diminuição da biomassa seca de $S$. auriculata com o aumento da concentração de Cd na solução. Em nível ultraestrutural, as folhas expostas ao $\mathrm{Cd}$ apresentaram má formação dos cloroplastos e deterioração da parede celular. Todos os sintomas de toxidade foram diretamente proporcionais à concentração de $\mathrm{Cd}$ na solução. Os resultados sugerem que $S$. auriculata apresenta um bom potencial para uso como bioindicador e pode ser usada em programas de biomonitoramento de ecossistemas aquáticos contaminados por $\mathrm{Cd}$.
\end{abstract}

Palavras-chave: planta aquática, metal pesado, indicador ecológico, biomonitoramento. 


\section{Introduction}

Aquatic ecosystems have been significantly altered by multiple environmental impacts in association with human disturbances (Jiang and Wang, 2007). Extensive use of fertilizers and intensification of industrial and mining activities contaminate watercourses and water-bearing stratum with heavy metals (Malavolta, 1994).

Heavy metal cadmium $(\mathrm{Cd})$ is a major concern due to its toxicity, high mobility among plants, and easy incorporation to the biological food-webs (Oliveira et al., 2001). Cd occurs naturally in aquatic environments in concentrations below $0.01 \mu \mathrm{g} . \mathrm{L}^{-1}$, yet in polluted waters it can be found in much higher concentrations (Devi et al., 1996). Cd may be introduced into the environment as a result of the industrial processing of leather and some metals, including zinc and lead. It is also present in phosphate fertilizers and used in paint and lubricant production (Jiang and Wang, 2007). In aquatic ecosystems, $\mathrm{Cd}$ can affect the biota indirectly by trophic transfer; fish accumulate metal in their tissues and they may transfer to the upper levels of the chain, like humans (Joyeux et al., 2004); or directly by absorption (Devi et al., 1996).

Symptoms of toxicity by heavy metals have been investigated in several plants and under various conditions (Clemens, 2006). The presence of $\mathrm{Cd}$ in plant growing environments inhibits physiological processes such as respiration, photosynthesis, and gas exchange, causing early senescence (Lagriffoul et al., 1998; Clemens, 2006).

Aquatic macrophytes have been used for monitoring the contamination level by various pollutants in aquatic environments (Sawidis et al., 1995), including organic matter and nutrients such as $\mathrm{P}$ and $\mathrm{N}$ in wetland systems (Borges et al., 2008) and heavy metals, such as Zn (Wolff et al., 2009), Hg (Molisani et al., 2006) and others as these plants have the ability to accumulate metallic ions (Devi et al., 1996). The use of these plants as bioindicators of contamination by heavy metals has advantages: a) high tolerance to the pollutant, b) easy sampling, c) selective absorption ability, and d) individuals are relatively big and easy to handle in laboratories (Lewis, 1995; Zhou et al., 2008).

Salvinia auriculata is a free-floating macrophyte, widely distributed in freshwater environments. Under favorable conditions, it reproduces rapidly and vegetatively, colonizing extensive areas in a short time (Henry-Silva and Camargo, 2006). Its high growth rate and sensitivity to different toxic agents favor the use of Salvinia as a bioindicator of pollution in aquatic ecosystems (Lewis, 1995; Gardner and Al-Hamdani, 1997).

Salvinia auriculata has been used as a bioindicator of presence and contamination levels of $\mathrm{Cd}$ in aquatic environments (Outridge and Hutchinson, 1990). However, its use has been limited due to morphological and population status, only evident where a high pollutant concentration is present.
Traditional methods to assess a stressing agent, such as alterations in the growth rate and species composition in a community, have been using inadequate indicators (Mendelssohn et al., 2001). It is necessary to use biological indicators capable of detecting, predicting and quantifying a stressing agent before large-scale visible damage and loss occur (Mendelssohn and McKee, 1992).

Bioassays are important tools to select better indicators. Several aquatic organisms at different trophic levels have been widely used in ecotoxicological assessments. Biological methods can provide a qualitative description of both the presence and toxicological potential of a certain pollutant. It is possible to expose an organism to different toxicity tests and then estimate the potential hazard of the pollutant (Feiler et al., 2006).

The aim of this work was to verify the response of Salvinia auriculata to water contamination by $\mathrm{Cd}$ in a ultrastructural, morphoanatomical and clonal growth level. The following hypotheses were tested: 1) S. auriculata decreases new ramet production and biomass allocation when exposed to $\mathrm{Cd}$; 2) $\mathrm{S}$. auriculata shows morphological and ultrastructural damage when exposed to $\mathrm{Cd}$.

\section{Material and Methods}

\subsection{The species}

Salvinia auriculata Aubl. (1775) (Pteridophyta: Salvinaceae), commonly known as "water fern", is a freefloating fern. The plant has ramets connected by rhizomes. Each ramet is formed by a node bearing two floating leaves, one submerged leaf, one apical bud, and some lateral buds. True roots are absent. The submerged leaf absorbs water and ions, functioning as a root (Sculthorpe, 1967). The submerged leaf is also responsible for spore production (De La Sota, 1962).

\subsection{Bioassay setup}

Salvinia auriculata samples were obtained from a reservoir in Grande River (44 $55^{\prime} \mathrm{W}$ and $\left.21^{\circ} 05^{\prime} \mathrm{S}\right)$, located in the state of Minas Gerais, Brazil. These aquatic plants were rinsed with distilled water and separated according to size uniformity. The ramets were cultivated in a greenhouse for 5 days, in pots with $25 \mathrm{~L}$ of Hogland's nutrient solution with $\mathrm{pH}$ between 6.5 and 7 , with $1 / 5$ of the original ionic strength (Hoagland and Arnon, 1950). The $\mathrm{pH}$ value was determined according to Olguín et al. (2002). During the experimental period the average temperature was $21.9^{\circ} \mathrm{C}$.

After the acclimatization period, each ramet was transferred to containers $(1.0 \mathrm{~L})$ filled with modified Hoagland-Arnon solution, where they were exposed to increasing concentrations of $\mathrm{Cd}\left(\mathrm{NO}_{3}\right)_{2}: 0.0 \mu \mathrm{mol} . \mathrm{L}^{-1}$ (Control), $1.0 \mu \mathrm{mol} . \mathrm{L}^{-1}$ (T1), $2.5 \mu \mathrm{mol} . \mathrm{L}^{-1}$ (T2), $5.0 \mu \mathrm{mol} . \mathrm{L}^{-1}$ (T3) and $10.0 \mu \mathrm{mol} . \mathrm{L}^{-1}$ (T4) for 10 days. The concentration chosen fell within the range of the $\mathrm{Cd}$ concentrations used in papers dealing with floating plants (Oliveira et al., 2001; Siriwan et al., 2006; Vestena et al., 2007). Each treatment had only one ramet per pot and four replications. 


\subsection{Clonal growth and biomass}

In order to determine clonal growth, the number of the new ramets were counted at the end of ten days to each treatment. Dry mass of floating and submerged leaves were used as an integral allocation measure. The floating and submerged leaves had their dry biomass determined separately. The samples were dried in an oven at $48{ }^{\circ} \mathrm{C}$ for 72 hours and then weighed.

\subsection{Morphologic and ultrastructural responses}

The leaves were observed daily to evaluate morphological changes. The scanning electron microscope (SEM) and transmission electron microscope (TEM) were used to analyse ultrastructural changes.

\subsection{Preparation of samples for scanning electron microscopy (SEM)}

For the microscopic analyses, two floating leaves from each replication were collected. The samples were cut lengthways and immersed in a modified Karnovisky solution (glutaraldehyde $2.5 \%$, paraformaldehyde $2.5 \%$ in sodium cacodylate buffer $0.05 \mathrm{M}, \mathrm{CaCl}_{2} 0.001 \mathrm{M}$, $\mathrm{pH}$ 7.2). They were then infiltrated with a cryoprotector, an aqueous solution consisting of $30 \%$ glycerol, for 30 minutes and transversally sectioned in liquid nitrogen using a scalpel blade. The cuts obtained were transferred to a $1 \%$ aqueous solution of osmium tetroxide for 1 hour and were subsequently dehydrated for 10 minutes in a series of acetone solutions $(25,50,75,90$ and $100 \%$ three times) before being taken to the critical point apparatus (Baltec CPD 030). The specimens were placed on aluminum support stubs placed over a film of aluminum foil using a carbon tape, sputter covered with gold (Baltec SCD 050) and observed in a LEO EVO 40 XVP scanning electron microscope (Leo Electron Microscopy).

\subsection{Preparation of samples for transmission electron microscopy (TEM)}

Samples of floating leaves of the $S$. auriculata were cut lengthways and immersed in a fixative solution (Karnovisky's modified), pH 7.2. They were then washed in a cacodylate buffer $0.05 \mathrm{M}, \mathrm{pH} 7.2$ (three times for 10 minutes), post-fixed in $1 \%$ aqueous osmium tetroxide solution for 1 hour, washed twice for 15 minutes in distilled water, transferred to a $0.5 \%$ uranyl acetate solution for 12 hours and then washed once more in distilled water and dehydrated in a series of acetone solutions $(25,50$, 75,90 and $100 \%$ three times). The dehydrated tissue was gradually infiltrated with spur/acetone, $30 \%$ for 8 hours, $70 \%$ for 12 hours and $100 \%$ twice for 24 hours each. The specimens obtained were set in moulds and polymerised at $70{ }^{\circ} \mathrm{C}$ for 48 hours forming blocks that were used in ultramicrotomy.

The blocks were trimmed having thickness thin $(0.85 \mu \mathrm{m})$ and ultra-thin $(<100 \mathrm{~nm})$ using a diamond knife in a Reichrt-jung ultramicrotome. The thin sections were selected using a gold ring, placed in glass microscope slides, colored with toluidine blue and set up permanently in a Permalt environment. The ultra-thin sections were taken in copper grids. The sections were post contrasted in uranyl acetate, followed by lead citrate for three minutes, and then examined with transmission electron microscopes (TEM) Zeiss Mod. EM-109.

\subsection{Data analysis}

To verify the response of $S$. auriculata to different levels of pollution by $\mathrm{Cd}$, a polynomial regression analysis was performed, considering the number of new ramets and dry biomass as variables responding to different concentrations of pollutant. An analyses of variance (ANOVA) with a complementary Tukey test (level of significance $=5 \%$ ) was performed to test the effect of the treatments on the number of ramets and biomass allocation.

\section{Results}

In this study, a multiple-level approach of the responses of Salvinia auriculata to cadmium pollution could be observed.

\subsection{Clonal growth and biomass responses}

It was not possible to observe the presence of reproductive structures in any of the treatments (including the control). The sprouting of new ramets of $S$. auriculata was observed only on the third and fourth days in the control sample, and only on the fifth day in all the other treatments. At the end of ten days, the control sample presented more ramets than the other treatments. The number of ramets decreased significantly relative to the increase of $\mathrm{Cd}$ concentration in the solution $(F=14,333 ; p=0,0001)$ (Figure 1a). The plant generated only one new ramet or none at the experiment with higher concentrations of $\mathrm{Cd}$ (T3 and T4).

The dry biomass decreased as $\mathrm{Cd}$ concentration increased in the solution. Treatment $\mathrm{T} 1$ presented a $49.5 \%$ reduction in biomass in relation to the control sample. This relation was more significant in the submerged leaf having a $72.4 \%$ biomass reduction (Figure 1b).

\subsection{Morphologic and ultrastructural responses}

After the fifth day of the experiment, it was observed that ramets exposed to higher $\mathrm{Cd}$ concentrations (5 and $10 \mu \mathrm{mol} . \mathrm{L}^{-1}$ ) presented toxicity symptoms, especially leaf chlorosis.

At the end of the experiment, a response gradient of S. auriculata to Cd contamination could be observed. The changes observed in the plant increased relative to the increase of metal concentration in the solution.

On the tenth day, all treatments presented external morphological damage, such as the occurrence of necrotized areas on the surface of leaves (Figure 2a). The necrotized areas presented dark brown pigmentation from the edge of the leaf toward the center. The pigmentation intensity was proportional to the metal concentration in the solution.

A deterioration in the cell wall was observed in treatment $\mathrm{T} 2$ and $\mathrm{T} 3$ due to loss of elasticity. In T4 the cell wall could not be identified by TEM analysis (Figure 2b). In 


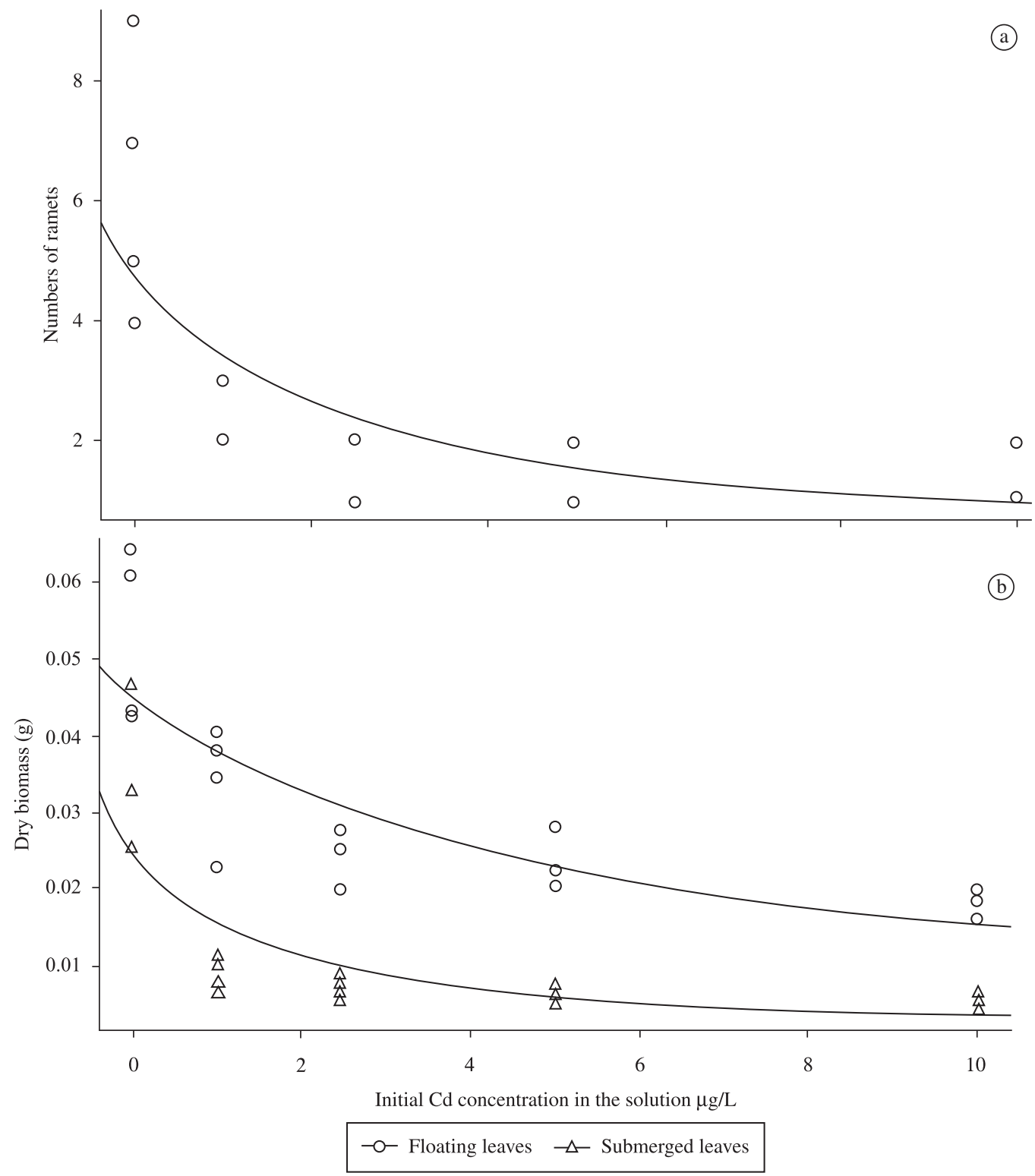

Figure 1. Clonal growth response of Salvinia auriculata as a function of Cd concentration in the solution, in $\mu$ mol. $\mathrm{L}^{-1}$, at the end of 10 days. a) Number of ramets $\left(R^{2}=0.52 ; p=0.0004 ; y=3.3636 x^{(-0.5-66)}\right)$. b) Dry biomass $(g)$ of aerial $\left(R^{2}=0.71\right.$; $\left.\mathrm{p}<0.0001 ; \mathrm{y}=0.0402 \mathrm{x}^{(-0.3793)}\right)$ and submerged portions $\left(\mathrm{R}^{2}=0.41 ; \mathrm{p}=0.0027 ; \mathrm{y}=0.0252 \mathrm{x}^{(-0.8442)}\right)$.

T1, a deposition of opaque material was observed along the middle lamella, giving it a sinuous shape (Figure $2 b$ ).

Exposure to $\mathrm{Cd}$ had significant effects on chloroplasts (Figure 2c). The chloroplasts of leaves treated with $\mathrm{Cd}$ were misshapen smaller and in a process of senescence.

It was possible to observe from the SEM that the leaves of $S$. auriculata are epistomatic, with anomocytic stomates and multicelullar non-glandular trichomes on both sides. With the absorption of $\mathrm{Cd}$ in leaf tissues, several structures relying on perfect development of the plasmatic membrane presented deformities. From T1, we observed the rupture of some epidermal cells and trichomes on the adaxial surface of the leaf (Figure 2d).
Treatments exposed to Cd also showed stomate deformations. Many stomates presented an open ostiole. No damage was observed in the aerenchymas, allowing plants to float even with high concentrations of $\mathrm{Cd}$.

\section{Discussion}

The absence of reproductive structures in the plants can be explained by low density of ramets and by availability of water in the experiment. According to Coelho et al. (2005), S. auriculata invest more in clonal growth than in sexual reproduction at low densities and in large-wateravailability conditions. 

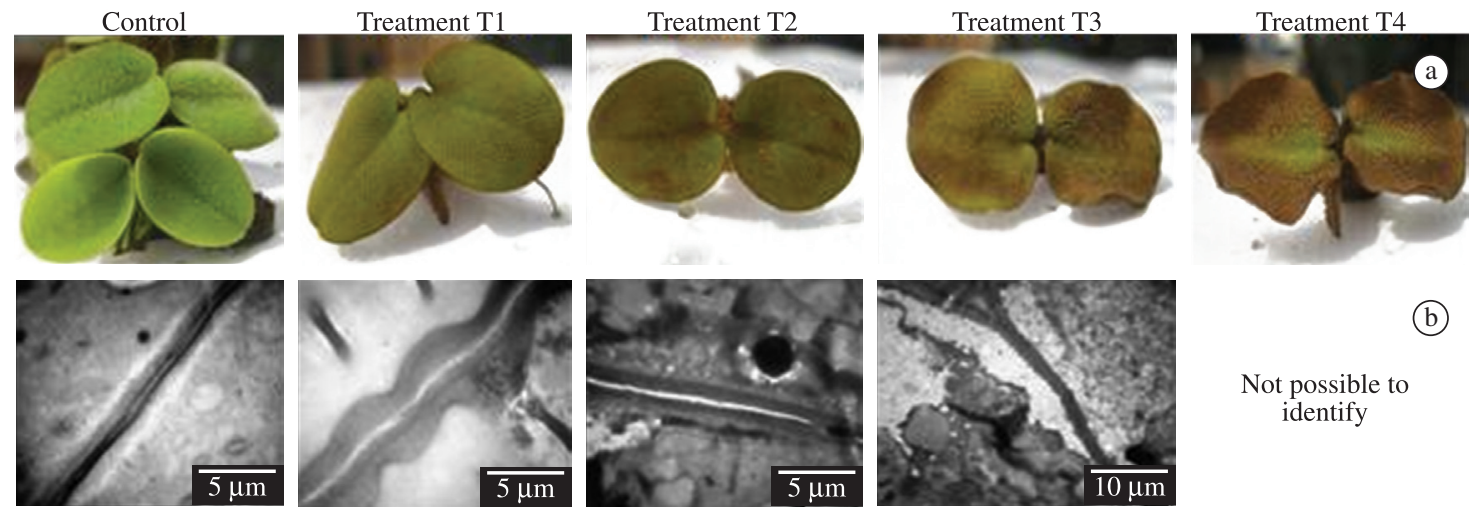

(b)

Not possible to identify
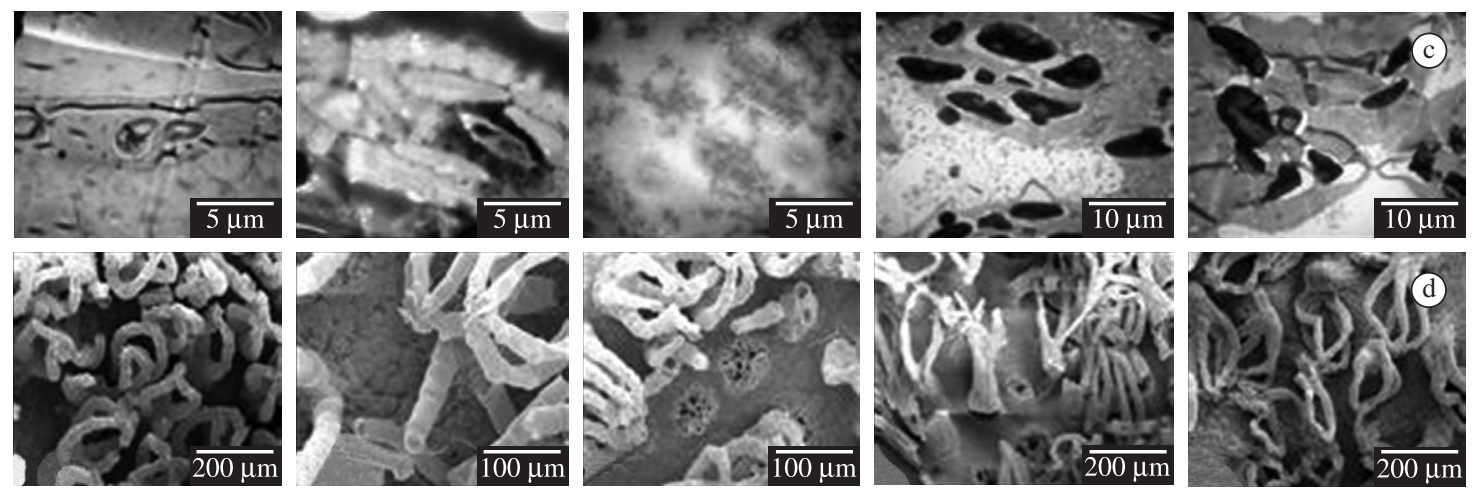

Figure 2. Structural responses in floating leaves from Salvinia auriculata to contamination by cadmium at the end of ten days. a) Morphological alterations; b) Cell wall (Control, T1 and T2 bar $=5 \mu \mathrm{m}$; T3 bar $=10 \mu \mathrm{m}$ ); c) Chloroplast (Control, $\mathrm{T} 1$ and T2; bar $=5 \mu \mathrm{m} ; \mathrm{T} 3$ and T4, bar $=10 \mu \mathrm{m}) ; \mathrm{d})$ Trichomes and epidermical cell (Control, T3 and T4 bar = $200 \mu \mathrm{m}$; T1 and $\mathrm{T} 2$, bar $=100 \mu \mathrm{m})$.

Cadmium is a non-essential element that negatively affects plant growth and development (Benavides et al., 2005).

Oliveira et al. (2001) observed that $S$. auriculata is not able to survive in high $\mathrm{Cd}$ concentrations and our results indicate that even concentrations of $10 \mu \mathrm{mol} . \mathrm{L}^{-1}$ were sufficient to kill individuals in 8 days. When exposed to chromium VI, S. minima presented a significant decrease in growth rate and biomass (Nichols et al., 2000). Similarly, barley plants exposed to $\mathrm{Cd}$ presented a reduced water percentage in both fresh and dry biomass, as well as a reduced average height of individuals (Sridhar et al., 2007).

The submerged leaves of $S$. auriculata are capable of absorbing water and ions, functioning as a root. Hence, the reduction in their biomass can be interpreted as a strategy to minimize the absorption of Cd. Larger 'roots' can be more efficient in the uptake of particles on water than smaller 'roots' (Room, 1988). Oliveira et al. (2001) also found a larger reduction in biomass of submerged leaves than in the biomass of floating leaves when S. auriculata was exposed to $\mathrm{Cd}$. The authors associated this relation to the greater absorption of $\mathrm{Cd}$ performed by these submerged leaves.

Aquatic plants exposed to heavy metals show typical symptoms, such as leaf and root necrosis (Vecchia et al., 2005; Souza et al., 2009), chlorosis, brownish-red coloration, reduced biomass and reduced yield (Oliveira et al., 2001;
Guimarães et al., 2006). This pattern is associated with stomatal opening, a reduced rate of photosynthesis, a reduced nutrient absorption and transportation (Larsson et al., 1998). A possible reason for the cadmium toxicity is its chemical similarity to ion $\mathrm{Fe}^{+2}$. Plants exposed to $\mathrm{Cd}$ present morphological damage because they have $\mathrm{Fe}^{+2}$ replaced with $\mathrm{Cd}^{+2}$ in many vital physiological processes (Stohs and Bagchi, 1995).

High concentrations of $\mathrm{Cd}$ in the roots influence the way they grow, affecting their morphology (coloration and trichome development) and architecture (number and length of side roots). This may inhibit the population growth (Breckle, 1991). Macrophytes can also undergo structural changes in response to contamination by heavy metals. (Zhou et al., 2008).

Metal toxicity may affect membrane permeability, thus causing a reduction in water content. This structure is the prime target of Cd phytotoxicity (Barceló and Poshevieder, 1990; Gupta and Devi, 1992).

In T1, the deposition of substances in the cell walls of epidermal cells could be an adaptive adjustment against cell-to-cell translocation of $\mathrm{Cd}$, thus avoiding transfer of this metallic ion to adjacent cells. This mechanism prevents degradation of the plasma membrane. The degradation of cell walls and plasma membrane in the other treatments could be the result of various mechanisms including the 
oxidation and cross-linking of protein thiols, inhibition of key membrane proteins or changes in the composition and fluidity of membrane lipids (Meharg, 1993).

When the cellular integrity is preserved (as observed in T1), the presence of an opaque material, with refraction index smaller than the cell wall, may cause cloudiness in the protoplastid, preventing the full development of chloroplasts.

The Cd causes oxidative stress. This may contribute to the aging of chloroplasts and cells (Dixit et al., 2001). Vecchia et al. (2005) observed that chloroplasts of leaves treated with $\mathrm{Cd}$ showed misshapen smaller in their study with Elodea canadensis. Chloroplasts are vital organelles in the photosynthesis process and with their deterioration, the photosynthetic rate may be altered. The photosynthetic activity decreases significantly with increasing Cd concentration, and is considered as a sensitive indicator of stress caused by this metal (Mendelssohn et al., 2001). Photosynthesis proved to be one of the most affected processes in soy plants subjected to $\mathrm{Cd}$ as this metal inhibits chlorophyll biosynthesis (Oliveira et al., 1994).

The Cd can still cause the rupture of epidermal cells leading to a deficiency of the lining system and consequently to a deficiency of the protection of the organs. As the trichomes are extensions of epidermal membranes, this rupture causes fragility in trichomes, thus losing their functional characteristic.

According to this study, leaves of $S$. auriculata exposed to different concentrations of $\mathrm{Cd}$ presented morphological and ultrastructural changes. They were also reduced in the numbers of ramets and biomass at the end of the experiment. These changes were all proportional to the concentration of Cd being applied. This study supports the potential use of this plant as an ecological indicator of $\mathrm{Cd}$ presence in contaminated environments. It presented sensitivity to the metal and damage was clearly visible and easily quantified.

Acknowledgements - The authors wish to thank the National Research and Development Council (CNPq), the Research Aid Foundation of Minas Gerais (FAPEMIG) and the Coordinating Board for Graduate Advancement (CAPES).

\section{References}

BARCELÓ, J. and POSCHEVIEDER, C., 1990. Plant water relations as affected by heavy metal stress: a review. Journal of Plant Nutrition, vol. 13, no. 1, p. 1-37. http://dx.doi.org/10.1080/01904169009364057

BENAVIDES, MP., GALLEGO, SM. and TOMARO, ML., 2005. Cadmium toxicity in plants. Brazilian Journal of Plant Physiology, vol. 17 , no. 1 , p. $21-34$

BORGES, AKP., TAUK-TORNISIELO, SM., DOMINGOS, RN. and ANGELIS, DF., 2008. Performance of the Constructed Wetland System for the Treatment of Water from the Corumbataí River. Brazilian Archives of Biology and Technology, vol. 51, p. $1279-1286$.

BRECKLE, SW., 1991. Growth under stress. Heavy metals. In WAISEL, Y., ESHEL, A. and KAFKAFI, U. (Eds.). The Plant Roots, the Hidden Half. New York: Marcel Dekker. p. 351-73.
CLEMENS, S., 2006. Toxic metal accumulation, responses to exposure and mechanisms of tolerance in plants. Biochimie, vol. 88, no. 11, p. 1707-1719. PMid:16914250. http://dx.doi. org/10.1016/j.biochi.2006.07.003

COELHO, FF., LOPES, FS. and SPERBER, CF., 2005. Persistence strategy of Salvinia auriculata aublet in temporary ponds of southern Pantanal, Brazil. Aquatic Botany, vol. 81, no. 4, p. 343352. http://dx.doi.org/10.1016/j.aquabot.2005.02.001

DE LA SOTA, ER., 1962. Contribución al conocimento de las Salviniaceae neotropicales. II. Salvinia auriculata Aublet. Darwiniana, vol. 12, p. 499-513.

DEVI, M., THOMAS, DA., BARBER, JT. and FINGERMAN, M., 1996. Accumulation and physiological and biochemical effects of cadmium in a simple aquatic food chain. Ecotoxicological and Environmental Safety, vol. 33, no. 1, p. 38-43. PMid:8744922. http://dx.doi.org/10.1006/eesa.1996.0004

DIXIT, V., PANDEY, V. and SHYAM, R., 2001. Differential antioxidative responses to cadmium in roots and leaves of pea (Pisum sativum L. cv Azad). Journal of Experimental Botany, vol. 52, p. 1101-1109. PMid:11432926. http://dx.doi.org/10.1093/ jexbot/52.358.1101

FEILER, U., KREBS, F. and HEININGER, P., 2006. Aquatic plant bioassays used in the assessment of water quality in German rivers. Hydrobiologia, vol. 570, no. 1, p. 67-71. http://dx.doi. org/10.1007/s10750-006-0163-7

GARDNER, JL. and AL-HAMDANI, SH., 1997. Interactive effects of aluminum and humic substances on salvinia. Journal of Aquatic Plant Management, vol. 35, p. 30-34.

GUIMARÃES, FP., GOMES, CQ., MAGALHÃES, ABS., FREITAS, TV., OLIVEIRA, JA. and AGUIAR, R., 2006. Estudos laboratoriais de acúmulo e toxicidade de arsênio em Eichhornia crassipes e Salvinia auriculata. Journal of the Brazilian Society of Ecotoxicology, vol. 1, no. 2, p. 109-113. http://dx.doi.org/10.5132/ jbse.2006.02.003

GUPTA, M. and DEVI, S., 1992. Cadmium sensitivity inducing structural responses in Salvinia molesta Mitchell. Bulletin of Environmental Contamination and Toxicology, vol. 49, no. 3, p. 436-443. PMid:1498482. http://dx.doi.org/10.1007/BF01239649

HENRY-SILVA, GG. and CAMARGO, AFM., 2006. Composição química de macrófitas aquáticas flutuantes utilizadas no tratamento de efluentes de aqüicultura. Planta Daninha, vol. 24, no. 1, p. 21-28.

HOAGLAND, DR. and ARNON, DI., 1950. The water-culture method for growing plants without soil. California: California Agricultural Experimental Station. $32 \mathrm{p}$.

JIANG, X. and WANG, C., 2007. Cadmium distribution and its effects on molybdate-containing hydroxylases in Phragmites australis. Aquatic Botany, vol. 86, no. 4, p. 353-360. http://dx.doi. org/10.1016/j.aquabot.2007.01.002

JOYEUX, JC., CAMPANHA-FILHO, EA. and JESUS, HC., 2004. Trace Metal Contamination in Estuarine Fishes from Vitória Bay, ES, Brazil. Brazilian Archives of Biology and Technology, vol. 47 , p. $765-774$.

LARSSON, EL., BORNMAN, JF. and ASP, H., 1998. Influence of UV-B radiation and $\mathrm{Cd}^{2+}$ on chlorophyll fluorescence, growth and nutrient content in Brassica napus. Journal of Experimental Botany, vol. 49, no. 323, p. 1031-1039. http://dx.doi.org/10.1093/ jexbot/49.323.1031 
LAGRIFFOUL, A., MOCQUOT, B., MENCH, M. and VANGRONSVELD, J., 1998. Cadmium toxicity effects on growth, mineral and chlorophyll contents, and activities of stress related enzymes in young maize plants (Zea mays L.). Plant and Soil, vol. 200, no. 2, p. 241-250. http://dx.doi. org/10.1023/A:1004346905592

LEWIS, MA., 1995. Use of freshwater plants for phytotoxicity testing: a review. Environmental Pollution, vol. 87, no. 3, p. 319336. http://dx.doi.org/10.1016/0269-7491(94)P4164-J

MALAVOLTA, E., 1994. Fertilizantes e seu impacto ambiental: micronutrientes e metais pesados, mitos, mistificações e fatos. São Paulo: ProduQuímica. 153 p.

MEHARG, AA., 1993. The role of the plasmalemma in metal tolerance in angiosperms. Physiologia Plantarum, vol. 88, p. 191198. http://dx.doi.org/10.1111/j.1399-3054.1993.tb01777.x

MENDELSSOHN, IA. and McKEE, KL., 1992. Indicators of environmental stress in wetland plants. In MCKENZIE, DH., HYATT, DE. and MCDONALD, VJ. (Ed.). Ecological indicators. New York: Elsevier. p. 603-624.

MENDELSSOHN, IA., MCKEE, KL. and KONG, T., 2001. A comparison of physiological indicators of sublethal cadmium stress in wetland plants. Environmental and Experimental Botany, vol. 46, no. 3, p. 263-275. http://dx.doi.org/10.1016/ S0098-8472(01)00106-X

MOLISANI, MM., ROCHA, R., MACHADO, W., BARRETO, RC. and LACERDA, LD., 2006. Mercury contents in aquatic macrophytes from two reservoirs in the Paraíba do Sul: Guandú river system, SE Brazil. Brazilian Journal of Biology, vol. 66, no. 1A, p. 101-107.

NICHOLS, PB., COUCH, JD. and AL-HAMDANI, SH., 2000. Selected physiological responses of Salvinia minima to different chromium concentrations. Aquatic Botany, vol. 68, no. 4, p. 313319. http://dx.doi.org/10.1016/S0304-3770(00)00128-5

OLGUÍN, EJ., HERNÁNDEZ, E. and RAMOS, I., 2002. The effect of both different light conditions and the $\mathrm{pH}$ value on the capacity of Salvinia minima Baker for removing cadmium, lead and chromium. Acta Biotechnologica, vol. 22, no. 1-2, p. 121-131. http://dx.doi.org/10.1002/1521-3846(200205)22:1/2\%3C121::AIDABIO121\%3E3.0.CO;2-F

OLIVEIRA, JA., CAMBRAIA, J., CANO, MAO. and JORDÃO, CP., 2001. Absorção e acúmulo de cádmio e seus efeitos sobre o crescimento relativo de plantas de salvinia e aguapé. Brazilian Journal of Plant Physiology, vol. 13, no. 3, p. 329-341.

OLIVEIRA, JA., OLIVA, MA. and CAMBRAIA, J., 1994. Effects of cadmium on chlorophyll contents and on peroxidase activity in soybean. Brazilian Journal of Plant Physiology, vol. 6, no. 2, p. 97-101.

OUTRIDGE, PM. and HUTCHINSON, TC., 1990. Effects of cadmium on integration and resource allocation in the clonal fern Salvinia molesta. Oecologia, vol. 84, no. 2, p. 215-223.
ROOM, PM., 1988. Effects of temperature, nutrients and a beetle on branch architecture of the floating weed Salvinia molesta and simulations of biological control. Journal of Ecology, vol. 76, p. 826-848. http://dx.doi.org/10.2307/2260576

SAWIDIS, T., CHETTRI, MK., ZACHARIADIS, GA. and STRATIS, JA., 1995. Heavy metals in aquatic plants and sediments from water systems in Macedonia, Greece. Ecotoxicology and Environmental Safety, vol. 32, no. 1, p. 73-80. PMid:8565880. http://dx.doi.org/10.1006/eesa.1995.1087

SCULTHORPE, CD., 1967. The biology of aquatic vascular plants. London: E. Arnold. 610 p.

SIRIWAN, P., MALEEYA, K., PRAYAD, P. and SUCHART, U., 2006. Toxicity and bioaccumulation of cadmium and lead in Salvinia cucullata. Journal of Environmental Biology, vol. 27, no. 4 , p. 645-652.

SRIDHAR, BB., HAN, M., FX., MONT, DL. and SU, Y., 2007. Effects of $\mathrm{Zn}$ and $\mathrm{Cd}$ accumulation on structural and physiological characteristics of barley plants. Brazilian Journal of Plant Physiology, vol. 19, no. 1, p. 15-22. http://dx.doi.org/10.1590/ S1677-04202007000100002

SOUZA, VL., SILVA, DC., SANTANA, KB., MIELKE, MS., ALMEIDA, AF., MANGABEIRA, PAO. and ROCHA, EA., 2009. Efeitos do cádmio na anatomia e na fotossíntese de duas macrófitas aquáticas. Acta Botânica Brasilica, vol. 23, p. 343-354.

STOHS, SJ. and BAGCHI, D., 1995. Oxidative mechanisms in the toxicity of metal ions. Free Radical Biology and Medicine, vol. 18, no. 2, p. 321-336. http://dx.doi.org/10.1016/08915849(94)00159-H

VECCHIA, FD., LA ROCCA, N., MORO, I., DE FAVERI, S., ANDREOLI, C. and RASCIO, N., 2005. Morphogenetic, ultrastructural and physiological damages suffered by submerged leaves of Elodea canadensis exposed to cadmium. Plant Science, vol. 168, no. 2, p. 329-338. http://dx.doi.org/10.1016/j. plantsci.2004.07.025

VESTENA, S., CAMBRAIA, J., OLIVA, MA and OLIVEIRA, JA., 2007. Cadmium accumulation by water hyacinth and salvinia under different sulfur concentrations. Journal of the Brazilian Society of Ecotoxicology, vol. 2, no 3, p. 269-274. http://dx.doi. org/10.5132/jbse.2007.03.010

WOLFF, G., ASSIS, LR., PEREIRA, GC., CARVALHO, JG. and CASTRO, EM., 2009. Efeito da toxidade do zinco em folhas de Salvinia auriculata cultivadas em solução nutritiva. Planta Daninha, vol. 27, no. 1, p. 133-137. http://dx.doi.org/10.1590/ S0100-83582009000100017

ZHOU, QA., ZHANG, J., FU, J., SHI, J. and JIANG, G., 2008. Biomonitoring: an appealing tool for assessment of metal pollution in the aquatic ecosystem. Analytica Chimica Acta, vol. 606, no. 2, p. 135-150. PMid:18082645. http://dx.doi.org/10.1016/j. aca.2007.11.018 
